Revista Brasil. Bot., V.31, n.3, p.399-408, jul.-set. 2008

\title{
Anatomy of the floral scape of Bromeliaceae ${ }^{1}$
}

\section{SUZANA LÚCIA PROENÇA ${ }^{2,3}$ and MARIA DAS GRAÇAS SAJO ${ }^{2}$}

(received: July 04, 2007; accepted: June 05, 2008)

\begin{abstract}
Anatomy of the floral scape of Bromeliaceae). This paper describes the anatomy of the floral scape for 12 species of Bromeliaceae, belonging to the subfamilies Bromelioideae, Tillandsioideae and Pitcairnioideae. Although all the scapes have a similar organization, there are variations in the structure of the epidermis, cortex and vascular cylinder. Such variations are described for the studied scapes and, when considered together they can help to identify the species. These aspects are described for each scape and discussed under a taxonomic point of view.
\end{abstract}

Key words - anatomy, Bromeliaceae, floral scape

RESUMO - (Anatomia do escapo floral de Bromeliaceae). Este trabalho descreve a anatomia do escapo floral de doze espécies de Bromeliaceae pertencentes às subfamílias Bromelioideae, Tillandsioideae e Pitcairnioideae e tem como objetivo ampliar o conhecimento anatômico da família e desse órgão em particular. Embora todos os escapos apresentem uma organização similar, observam-se variações na estrutura da epiderme, do córtex e do cilindro vascular. Tais variações são descritas para os escapos estudados e, quando são analisadas em conjunto, podem auxiliar na identificação das espécies. Esses aspectos são descritos para cada um dos escapos e discutidos dentro de um contexto taxonômico.

Palavras-chave - anatomia, Bromeliaceae, escapo floral

\section{Introduction}

Bromeliaceae comprises about 2,600 Neotropical species, except for Pitcairnia feliciana (A. Chev.) Harms \& Mildbraed that occurs in West Africa (Smith and Till 1998). It is included in the order Poales (APG II 2003), close to the Typhaceae (Typha e Sparganium) and Rapateaceae (Bremer 2002, Davis et al. 2004, Linder \& Rudall 2005), and has traditionally been divided in to three subfamilies: Pitcairnioideae, Tillandsioideae and Bromelioideae, according to the growth habit, the ovary position and fruit and seed morphology (Smith \& Downs 1974, 1977, 1979). Recent phylogenetic analyses (Crayn et al. 2000, Horres et al. 2000, Barfuss et al. 2005) confirmed the monophyly of the Bromelioideae and Tillandsioideae, but indicated the Pitcairnioideae as a polyphyletic group (Crayn et al. 2000, Horres et al. 2000).

Bromeliaceae plants are herbaceous with reduced stems usually covered with spiraled leaves although in some cases distichous or subdistichous phyllotaxy also occurs. The simple or composed inflorescence is borne on a terminal scape or, sometimes, on a lateral scape originating from lateral buds (Smith \& Downs 1974, 1977, 1979).

1. Part of $\mathrm{PhD}$ thesis developed at Universidade Estadual Paulista Rio Claro, SP, Brazil.

2. Universidade Estadual Paulista, Instituto de Biociências, Departamento de Botânica, Caixa Postal 199, 13506-900 Rio Claro, SP, Brazil.

3. Corresponding author: suzanaproenca@ hotmail.com
There are few studies on the floral scape anatomy of Bromeliaceae, the more important is Tomlinson's revision (1969) of the results of Mez (1896 apud Tomlinson 1969), Solereder and Meyer (1929) and Foster (1945 apud Tomlinson 1969). Using these results Tomlinson (1969) comments the distribution of the vascular pattern in the central cylinder of the scape amongst the three subfamilies. Lately, Segecin \& Scatena (2004a) described the floral scape anatomy of 11 Tillandsia species focusing on to find features of taxonomic importance and of adaptive value to the epiphytic habit.

The present study supplies anatomical data of the floral scape of 12 Bromeliaceae growing in the cerrado areas of São Paulo State and discuss these results in a taxonomic context.

\section{Materials and methods}

The material was collected in their natural environment on the cerrado remnants of São Paulo State. The vouchers, deposited at the Herbário Rioclarense (HRCB), are registered as follow in the table 1 .

The scapes of at least two representatives of each species were fixed in FAA in ethanol 50\% (Johansen 1940) for $48 \mathrm{~h}$ and stored in $50 \%$ ethanol. Cross sections were made by free hand in the median third of all the scapes collected. The sections were stained with safranin and Astra blue (Bukatsch 1972 modified by Kraus \& Arduin 1997) and mounted on slides with glycerinated gelatin (Kaiser 1880).

Sections of fresh material were used to test the presence/ absence of phenolic compounds (Johansen 1940), starch (Johansen 1940), lignin (Sass 1951), lipids compounds 
Table 1. Species of Bromeliaceae studied.

\begin{tabular}{|c|c|c|}
\hline Subfamily/Species & Locality & Voucher \\
\hline \multicolumn{3}{|l|}{ BROMELIOIDEAE } \\
\hline Acanthostachys strobilacea (Schult. f.) Klotzsch & Reserva Biológica de Moji-Guaçu & S.L. Proença 201 \\
\hline Aechmea bromeliifolia (Rudge) Baker & Área de Proteção Ambiental de Corumbataí & S.L. Proença 212 \\
\hline Ananas ananassoides (Baker) L. B. Sm. & $\begin{array}{l}\text { Estação Experimental de Itirapina } \\
\text { Área de Proteção Ambiental de Corumbataí } \\
\text { Universidade de São Paulo, Campus de Pirassununga }\end{array}$ & $\begin{array}{l}\text { S.L. Proença } 192 \\
\text { S.L. Proença } 205 \\
\text { S.L. Proença } 214\end{array}$ \\
\hline Billbergia distachia (Vell.) Mez & Reserva Biológica de Moji-Guaçu & S.L. Proença 208 \\
\hline Billbergia porteana Brongn. ex Beer & Reserva Biológica de Moji-Guaçu & S.L. Proença 198 \\
\hline \multicolumn{3}{|l|}{ PITCAIRNIOIDEAE } \\
\hline Dyckia tuberosa (Vell.) Beer & $\begin{array}{l}\text { Estação Experimental de Itirapina } \\
\text { Universidade de São Paulo, Campus de Pirassununga }\end{array}$ & $\begin{array}{l}\text { S.L. Proença } 196 \\
\text { S.L. Proença } 213\end{array}$ \\
\hline \multicolumn{3}{|l|}{ TILLANDSIOIDEAE } \\
\hline Tillandsia loliacea Mart. ex Schult. f. & Área de Proteção Ambiental de Corumbataí & S.L. Proença 202 \\
\hline Tillandsia pohliana $\mathrm{Mez}$ & $\begin{array}{l}\text { Reserva Biológica de Moji-Guaçu } \\
\text { Pratânia/cerrado }\end{array}$ & $\begin{array}{l}\text { S.L. Proença } 186 \\
\text { S.L. Proença } 216\end{array}$ \\
\hline Tillandsia recurvata (L.) L. & $\begin{array}{l}\text { Reserva Biológica de Moji-Guaçu } \\
\text { Estação Experimental de Itirapina } \\
\text { Pratânia }\end{array}$ & $\begin{array}{l}\text { S.L. Proença } 190 \\
\text { S.L. Proença } 194 \\
\text { S.L. Proença } 215\end{array}$ \\
\hline Tillandsia tenuifolia $\mathrm{L}$. & Reserva Biológica de Moji-Guaçu & S.L. Proença 189 \\
\hline Tillandsia tricholepis Baker & $\begin{array}{l}\text { Estação Experimental de Itirapina } \\
\text { Área de Proteção Ambiental de Corumbataí }\end{array}$ & $\begin{array}{l}\text { S.L. Proença } 195 \\
\text { S.L. Proença } 204\end{array}$ \\
\hline Vriesea sp. & Estação Experimental de Itirapina & S.L. Proença 217 \\
\hline
\end{tabular}

(Gerlach 1984) and to determine the crystals chemical nature (Chamberlain 1932).

The results were registered on a photomicroscope Olympus BX40.

\section{Results}

The scapes of Bromelioideae and Tillandsioideae originate from the rhizome apical meristem and those of the Pitcairnioideae Dyckia tuberosa (Vell.) Beer have an axillary origin. Most of the studied species have erect scapes but they are pendent in the Bromelioideae Billbergia porteana and Acanthostachys strobilacea. The scape bears composed inflorescences in Vriesea sp. (Tillandsioideae) and D. tuberosa (Pitcairnioideae) and simple inflorescences in the other species. Within Tillandsioideae, the Tillandsia inflorescence have two to ten flowers that may be up to $2.5 \mathrm{~cm}$ long; in Vriesea $\mathrm{sp}$., the inflorescence is multi-flowered and each flower is around $5 \mathrm{~cm}$ long. In the Bromelioideae and Pitcairnioideae, each scape bears many flowers that can be up to $9 \mathrm{~cm}$ long.

In cross-section, the scapes are cylindrical and covered by a cuticle of variable thickness (figures 1,2 ,
$3,4)$. The epidermis is one-layered and its cells are of different size and shape (figures 1-11) and contain spherical silica bodies (figures 1,2 ). In most Bromelioideae Ananas ananassoides (figure 1), Aechmea bromeliifolia (figures 2, 9), Billbergia porteana (figure 6) and Acanthostachys strobilacea (figure 8), all the epidermal cells have thickened and lignified walls although in $B$. distachia the thickened walls are of cellulosic nature as in the Tillandsioideae Tillandsia loliacea (figures 11, 14) and T. tenuifolia scapes. In T. pohliana (figures 3, 7, 16) all the epidermal cells have thickened and lignified walls but in the others Tillandsioideae Tillandsia recurvata (figures 5, 10), $T$. tricholepis (figure 15) and Vriesea sp., as well as in the Pitcairnioideae Dyckia tuberosa (figure 13), the epidermal cells have thickened walls, although the outer periclinal wall is cellulosic and the others lignified. In all Tillandsia species the outer periclinal wall is convex and the inner is concave (figures 4, 5, 10, 11, 15), except for T. pohliana (figure 3 ).

The stomata are sunken in the scape epidermis of T. pohliana (figure 7) while in Acanthostachys strobilacea (figure 8) the scape surface presents marked depressions 

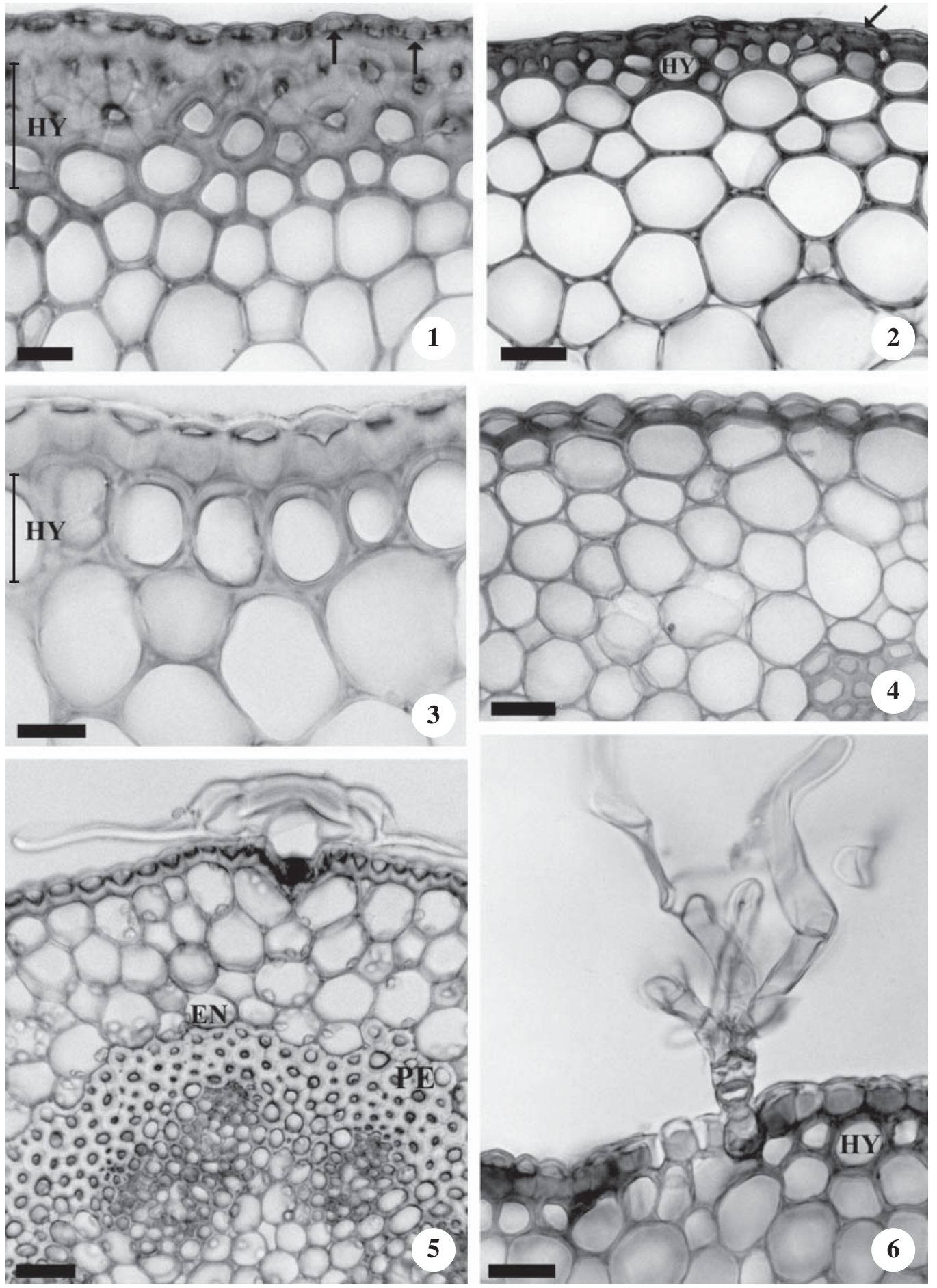

Figures 1-6. Cross section of floral scapes. 1. Ananas ananassoides. 2. Aechmea bromeliifolia. 3. Tillandsia pohliana. 4. Tillandsia tricholepis, without mechanical hypodermis. 5. Tillandsia recurvata, showing scale and pericycle fibers limiting the central cylinder. 6. Billbergia porteana, showing stellate trichome. The arrows indicate spherical silica bodies inside epidermal cells. $(\mathrm{HY}=$ mechanical hypodermis; $\mathrm{EN}=$ endodermis; $\mathrm{PE}=$ pericycle $) . \mathrm{Bar}=20 \mu \mathrm{m}(2,3,4,6), 30 \mu \mathrm{m}(1,5)$.

(figure 19), where the sunken stomata (figure 8) and the scales are located. In Aechmea bromeliifolia (figure 9), Ananas ananassoides, Billbergia distachia, Billbergia porteana, Dyckia tuberosa and Tillandsia tenuifolia the stomata are project above epidermis level, while in $T$. recurvata (figure 10), T. loliacea (figure 11), T. tricholepis and Vriesea sp., they occupy the same level of the other epidermal cells (table 2). 


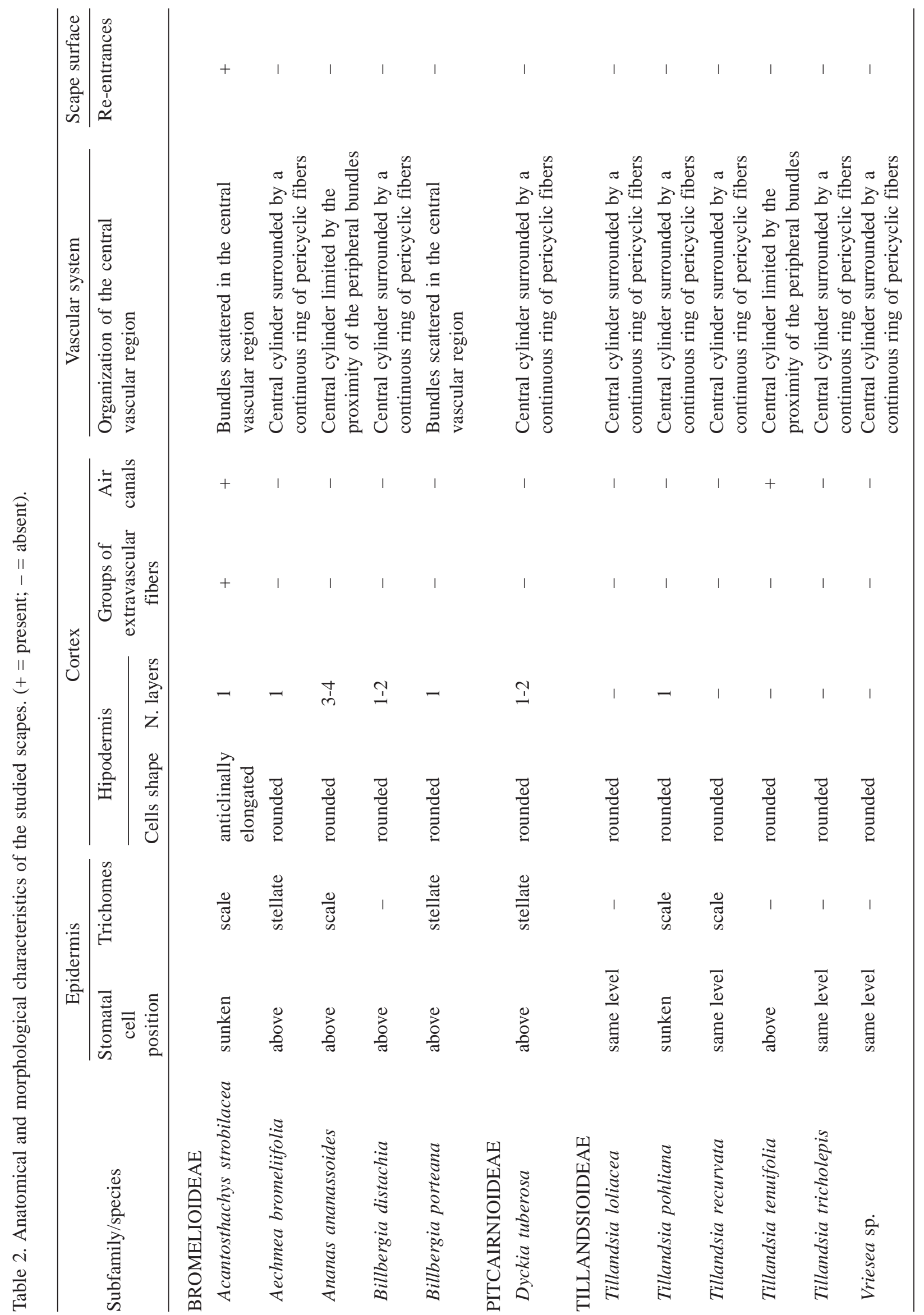




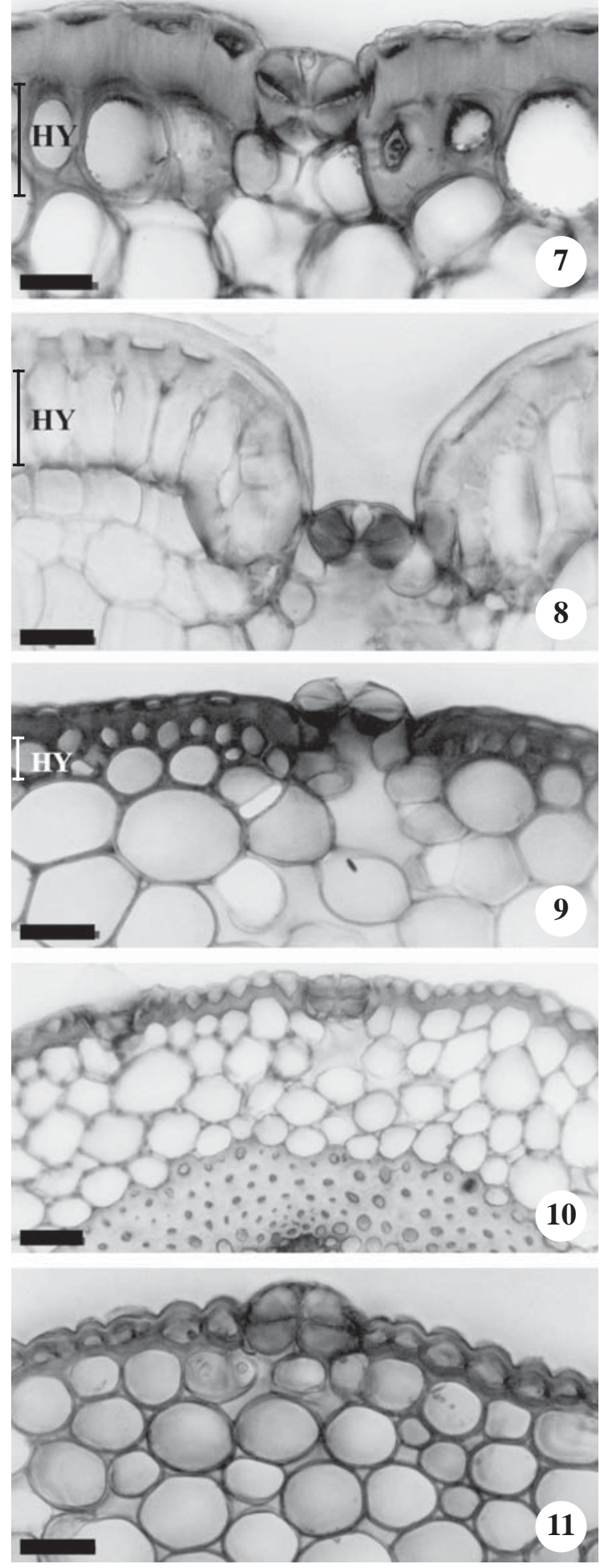

Figures 7-11. Cross section of floral scapes. 7. Tillandsia pohliana, with stomata bellow the epidermis cells level. 8 . Acanthostachys strobilacea, with stomata deeply below the epidermis cells level. 9. Aechmea bromeliifolia, with stomata above epidermis cells level. 10. Tillandsia recurvata, with stomata at the same level as the epidermis cells. 11. Tillandsia loliacea, with stomata at the same level as the epidermis cells. $(\mathrm{HY}=$ hypodermis $) . \mathrm{Bar}=20 \mu \mathrm{m}(7,8,9,11), 30 \mu \mathrm{m}(10)$.
Stellate trichomes occur in the scapes of $B$. porteana (figure 6), Aechmea bromeliifolia and D. tuberosa, and scales in those of $T$. recurvata (figure 5), Acanthostachys strobilacea, Ananas ananassoides and T. pohliana (table 2). No epidermal appendage was observed for the scapes of B. distachia, T. loliacea, T. tricholepis, T. tenuifolia and Vriesea sp. (table 2).

The cortex is parenchymatous with small intercellular spaces and its rounded cells are of different size (figures 1-6, 9-19). A hypodermis of sclerified cells forms one layer in the scape of Aechmea bromeliifolia (figures 2, 9), B. porteana (figure 6), T. pohliana (figures 3,7 ) and Acanthostachys strobilacea (figures 8, 19) and 3-4 layers in the scape of Ananas ananassoides (figure 1) (table 2). The hypodermis is also 1-2 layered in $D$. tuberosa (figure 13) and B. distachia but its thick walled cells are of cellulosic nature (table 2). In Acanthostachys strobilacea, the hypodermis cells are anticlinally elongated (figure 8). A morphologically differentiated hypodermis is absent in the scape of the others Tillandsia (figures 4, 5, 10, 11, 14, 15) and of Vriesea sp. (figure 12) (table 2). Groups of scattered fibers occur on the peripheral region of the scape cortex in Acanthostachys strobilacea (figure 19). In this species, as well as in $T$. tenuifolia, air canals were observed between the bracts traces (figure 19). In all scapes, the endodermis does not present Casparian strips or starch grains being recognized only by its position (figure 5). Idioblasts of calcium oxalate raphides are frequent in all scapes especially in the cortex region (figures 13, 14, 16-18).

Collateral bundles randomly dispersed form the vascular system; these bundles can be partially or completely surrounded by sclerified cells (figures 5, 1219). In the Bromelioideae B. porteana (figure 18) and Acanthostachys strobilacea (figure 19) all the vascular bundles are scattered in the scape center and there is no clear distinction between the cortex and the central cylinder (table 2). In the scapes of the Bromelioideae Ananas ananassoides (figure 17) and of the Tillandsioideae $T$. tenuifolia, the limit between the central cylinder and the cortex is made only by the proximity of the peripheral bundles (table 2). However, in Ananas ananassoides these bundles are smaller and surrounded by more fiber layers than the central ones (figure 17) while in T. tenuifolia all the bundles are of a similar size and surrounded by cellulosic thick-walled cells. In the scape of most Tillandsioideae Tillandsia recurvata (figure 5), Vriesea sp. (figure 12), T. loliacea (figure 14), T. tricholepis (figure 15) and T. pohliana (figure 16), of the Pitcairnioideae D. tuberosa (figure 13) and of the Bromelioideae Aechmea bromeliifolia and $B$. distachia, the peripheral bundles of the central 

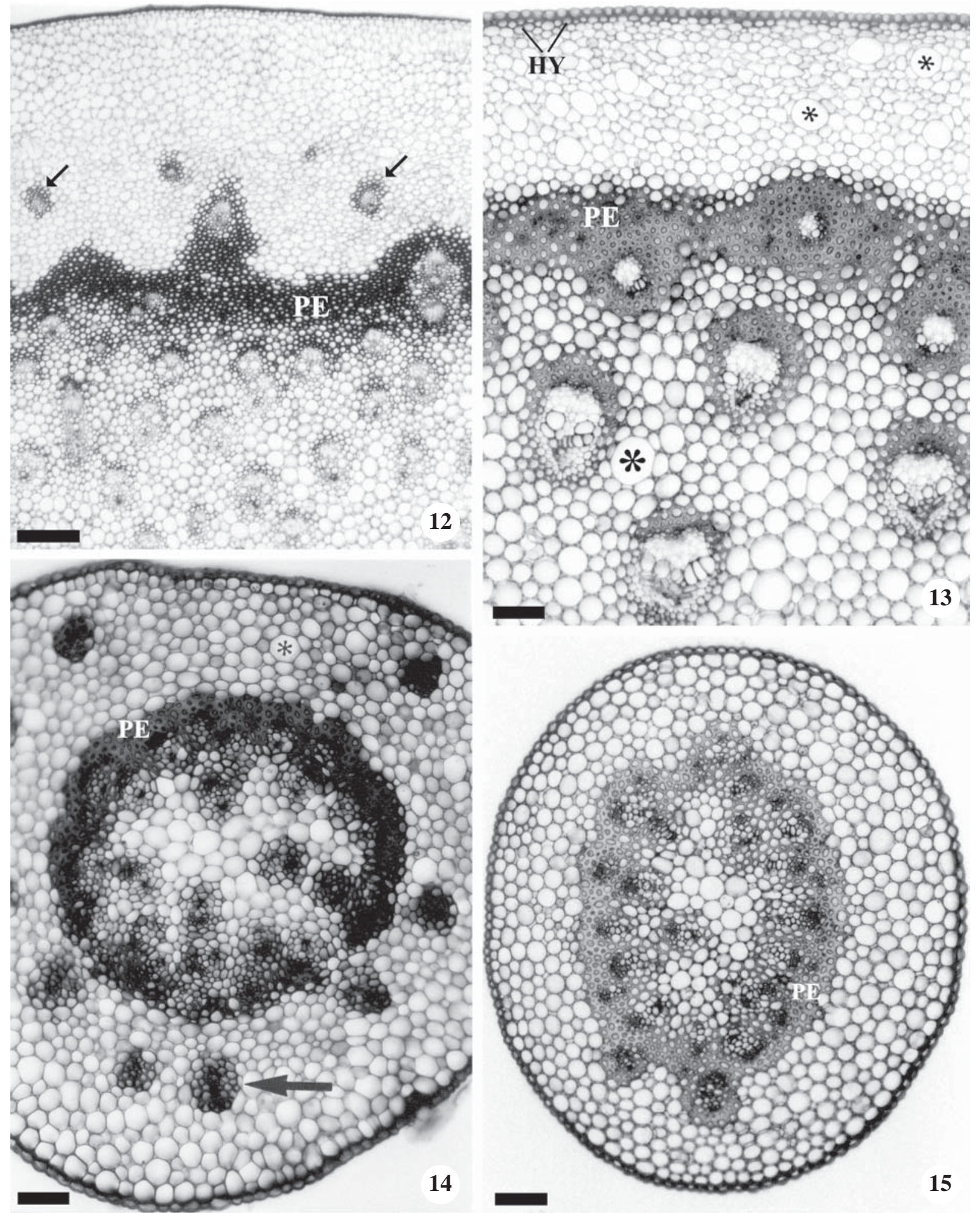

Figures 12-15. Cross sections of floral scapes with perycicle fibers limiting the vascular cylinder. 12. Vriesea sp. 13. Dyckia tuberosa. 14. Tillandsia loliacea. 15. Tillandsia tricholepis. The arrows indicate bract traces. $(\mathrm{HY}=$ hypodermis; $\mathrm{PE}=$ pericycle; $*=$ idioblasts of raphides). Bar $=70 \mu \mathrm{m}(13,14,15), 200 \mu \mathrm{m}(12)$. 

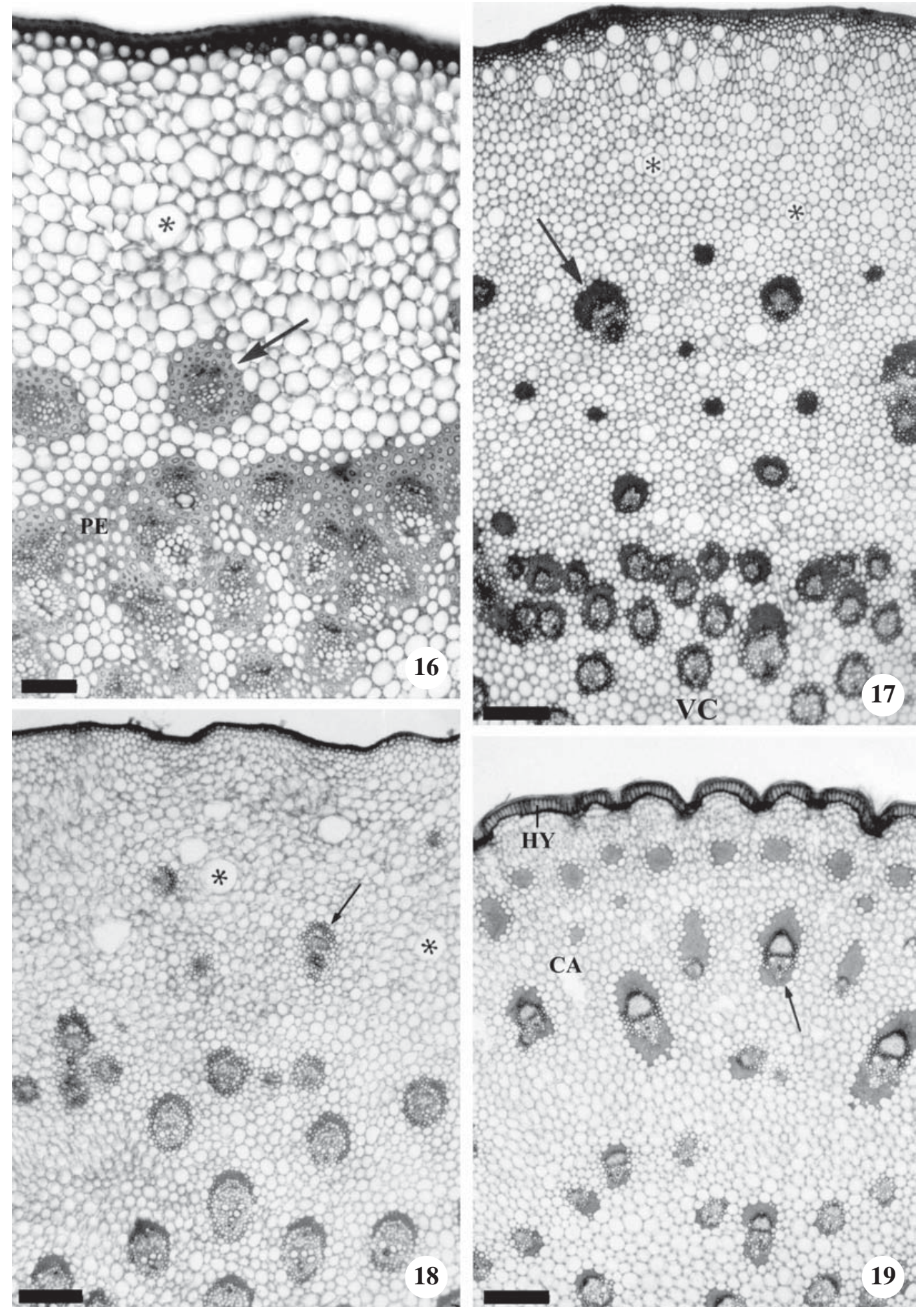

Figures 16-19. Cross section of floral scapes. 16. Tillandsia pohliana, showing aggregated vascular bundles surrounded by pericycle fibers on the periphery of the central cylinder. 17. Ananas ananassoides, with aggregated vascular bundles on the vascular cylinder periphery. 18. Billbergia porteana, showing vascular bundles scattered in the scape central region. 19. Acanthostachys strobilacea, with vascular bundles scattered in the scape central region; note the re-entrances on the epidermis and the cortical groups of extravascular fibers. The arrows indicate trace of bracts. $(\mathrm{CA}=$ air canal; $\mathrm{HY}=$ hypodermis; $\mathrm{PE}$ $=$ pericycle; $\mathrm{VC}=$ vascular cylinder; $*$ = idioblasts of raphides $) . \mathrm{Bar}=70 \mu \mathrm{m}(16), 200 \mu \mathrm{m}(17,18,19)$. 
cylinder are surrounded by a continuous ring of pericyclic cells with thick, lignified walls (table 2). This ring is only discontinuous where the bract traces pass through (figures $12,14,16)$.

\section{Discussion}

The scapes vary in size and structure being the inflorescences usually small and few flowered in Tillandsia and larger with many flowers in Vriesea sp. and in the representatives of Bromelioideae and Pitcairnioideae, as reported by Smith \& Downs $(1974,1977,1979)$. Most of the species have erect scape, except for B. porteana and Acanthostachys strobilacea (Bromelioideae) with pendent ones. The scapes of these two species are also similar in the scattered distribution of the bundles and in the absence of a clear limit between the central cylinder and the cortex. Although Tomlinson (1969) describes the occurrence of a ring of developed vascular bundles limiting the central cylinder of the Acanthostachys strobilacea scape, no clear limit between the cortex and the cylinder was observed here. However, we observed vascular bundles in more than one series in the cortical region, as described by Tomlinson (1969), besides extravascular fibers, not mentioned by this author.

Considering the other studied species, it is possible to recognize two types of scapes based on the central cylinder bundles arrangement: a) in the first one, the peripheral bundles are close together and delimit the central cylinder from the cortex; b) in the second, the peripheral bundles are surrounded by a ring of pericyclic fibers that demarcates the cylinder from the cortex. Thus, the scapes of the Bromelioideae Ananas ananassoides and of the Tillandsioideae T. tenuifolia belong to the first type. The scape of the others Bromelioideae (Aechmea bromeliifolia and B. distachia) and Tillandsioideae ( $T$. pohliana, $T$. loliacea, $T$. recurvata, $T$. tricholepis and Vriesea sp.) as well as that of D. tuberosa (Pitcairnioideae) fit in the second pattern.

Within Bromelioideae, the floral scapes of Acanthostachys strobilacea are distinct by the presence of re-entrances on its surface, where the stomata and scales are located, by the occurrence of a one-layered hypodermis of anticlinally elongated cells with thick lignified walls, and by the occurrence of groups of fibers and air canals in the cortex. Both in Aechmea bromeliifolia and $B$. porteana, the scapes have a one-layered hypodermis but its cells are not anticlinally developed and, in these cases, the stomata are projected on the epidermis level and there are stellate trichomes on the surface. However, they differ in the central cylinder organization. In Ananas ananassoides, the scape has a (3-4)-layered hypodermis of rounded sclerified cells, stomata projected on the epidermis level and scales on the surface. The scapes of B. distachia have no differentiated hypodermis and neither trichomes or scales on the epidermis. Within Billbergia, the scapes of B. porteana (subgenus Helicoidea) and $B$. distachia (subgenus Billbergia) differ in the central cylinder organization: in $B$. porteana, the bundles are scattered in the center and there is no clear distinction between the cortex and the central cylinder, while in B. distachia the bundles are grouped in the periphery of the cylinder and surrounded by a continuous ring of pericyclic cells of lignified walls. Furthermore, in the scapes of $B$. porteana there are trichomes (absent in B. distachia) as well as lignified epidermal and hypodermal cells (cellulosic in B. distachia). The anatomical characteristics of the epidermis, cortex and vascular cylinder vary for the studied scapes and, when considered together they can help to identify the species.

Within Tillandsioideae, the scape of T. pohliana has a one-layered hypodermis of lignified cells, sunken stomata and epidermal scales. The scapes of the others Tillandsioideae have an undifferentiated hypodermis and stomata leveled with the epidermis or occupying a higher position; only in $T$. pohliana and $T$. recurvata were observed scales. In Vriesea sp. the central cylinder is clearly limited by a ring of pericyclic fibers. Central cylinder clearly limited by a ring of pericyclic fibers also occurs in the scapes of Tillandsia that belong to the subgenus Diaphoranthema (T. loliacea, $T$. recurvata and T. tricholepis) and in T. pohliana (subgenus Anoplophytum). For T. recurvata, Segecin \& Scatena (2004a) reported this same feature for specimens that occupy gallery forests or rocky outcrops. A vascular cylinder demarcated only by the proximity of the peripheral bundles characterizes the scape of T. tenuifolia, also included in the subgenus Anoplophytum. Such characteristic also was observed for this species by Segecin \& Scatena (2004a) as well as air canals in the cortex. Tomlinson (1969) also reported variations in the cylinder structure of these two subgenera (Diaphoranthema and Anoplophytum) suggesting that this feature is not a good diagnostic for the Tillandsia species.

Silica bodies are frequent inside the scape epidermal cells. Since these bodies are indigestible, their presence has been associated with the plant resistance to the insects and fungi attack and since they are highly refractive too their presence has been associated with transpiration reduction (Krauss 1949a, Yoshida et al. 1962). Silica bodies also occur in other Poales, such as Poaceae, Cyperaceae, Thurniaceae, Rapateaceae, Centrolepidaceae, 
Ecdeiocoleaceae and Joinvilleaceae (Prychid et al. 2004), suggesting that this feature is a plesiomorphy for the order. In Bromeliaceae, the silica bodies are always of spherical shape and only occur in the epidermal cells as reported by Krauss (1948, 1949a), Tomlinson (1969), Flores (1975), Souza \& Neves (1996), Sajo et al. (1998), Aoyama \& Sajo (2003), Arruda \& Costa (2003), Proença $\&$ Sajo (2004), Scatena \& Segecin (2005), Sousa et al. (2005) and Proença \& Sajo (2007) for both vegetative and reproductive organs. This fact corroborates the supposition of Prychid et al. (2004) for whom the shape and localization of these bodies, although genetically controlled and little influenced by environmental factors, can present a systematic potential for some groups of monocotyledons.

Calcium oxalate raphides are particularly common in the cortical region of all studied scapes. The occurrence of raphides also has been registered in both vegetative and reproductive organs of Bromeliaceae (see Krauss 1948, 1949a, b; Braga 1977; Brighigna et al. 1984; Souza \& Neves 1996; Arruda \& Costa 2003; Aoyama \& Sajo 2003; Segecin \& Scatena 2004a, b; Sajo et al. 2004, 2005; Scatena \& Segecin 2005; Sousa et al. 2005; Proença \& Sajo 2007). Within Poales (APG II 2003), such crystals occur in Eriocaulaceae, Joinvilleaceae, Sparganiaceae and Typhaceae (Dahlgren et al. 1985) and probably represent a plesiomorphy for the order. Although the presence or absence of a determinate crystal has a taxonomic value in some groups (Prychid \& Rudall 1999), the presence of calcium oxalate crystals is generalized within Bromeliaceae and thus do not constitute a good feature to group or separate the family taxa.

According to Brighigna et al. (1984), calcium oxalate crystals neutralize the oxalic acid produced by the plants and can represent either forms of calcium and oxalic acid storage, reintroduced in the metabolism when necessary (Sunell \& Healey 1979), or deposits of metabolic wastes that would otherwise be toxic to the cell or tissue (Prychid \& Rudall 1999). For Mauseth (1988), Finley (1999) and Prychid \& Rudall (1999), the calcium oxalate raphides also make the plants little palatable to herbivores. According to Fahn \& Cutler (1992) these crystals has been considered to be of adaptive value in xerophytic conditions. However, the occurrence of raphides has been registered in many bromeliads that occupy different habitats (see Braga 1977; Arruda \& Costa 2003; Segecin \& Scatena 2004a, b; Sousa et al. 2005; Proença \& Sajo 2007), indicating that, in this case, the presence of such crystals is not related to water availability in the environment.
Acknowledgements - We thank CNPq (Conselho Nacional de Desenvolvimento Científico e Tecnológico) for a doctoral fellowship (first author) and a Researcher fellowship (second author), and Projeto Biota - FAPESP (Fundação de Amparo à Pesquisa do Estado de São Paulo) for financial support.

\section{References}

AOYAMA, E.M. \& SAJO, M.G. 2003. Estrutura foliar de Aechmea Ruiz \& Pav. subgênero Lamprococcus (Beer) Baker e espécies relacionadas (Bromeliaceae). Revista Brasileira de Botânica 26:461-473.

APG (Angiosperm Phylogeny Group). 2003. An update of the Angiosperm Phylogeny Group classification for the orders and families of flowering plants: APG II. Botanical Journal of the Linnean Society 141:399-436.

ARRUDA, R.C.O. \& COSTA, A.F. 2003. Foliar anatomy of five Vriesea sect. Xiphion (Bromeliaceae) species. Selbyana 24:180-189.

BARFUSS, M.H.J., SAMUEL, R., TILL, W. \& STUESSY, T.F. 2005. Phylogenetic relationships in subfamily Tillandsioideae (Bromeliaceae) based on DNA sequence data from seven plastid regions. American Journal of Botany 92:337-351.

BRAGA, M.M.N. 1977. Anatomia foliar de Bromeliaceae da Campina. Acta Amazonica 7:1-74.

BREMER, K. 2002. Gondwanan evolution of the grass alliance of families (Poales). Evolution 56:1374-1387.

BRIGHIGNA, L., FIORDI, A.C. \& PALANDRI, M.R. 1984. Structural characteristics of mesophyll in some Tillandsia species. Phytomorphology 34:191-200.

CHAMBERLAIN, C.J. 1932. Methods in plant histology. The University of Chicago Press, Chicago.

CRAYN, D.M., RANDALL, G.T., SMITH., J.A.C. \& WINTER, K. 2000. Molecular systematics investigations in Pitcairnioideae (Bromeliaceae) as a basis for understanding the evolution of crassulacean acid metabolism (CAM). In Monocots: systematic and evolution (K.L. Winter \& D.A. Morrison, eds.). CSIRO Publishing, Melbourne, p.569-579.

DAHLGREN, R.M.T., CLIFFORD, H.T. \& YEO, P.F. 1985. The families of the monocotyledons. Structure, evolution, and taxonomy. Academic Press, London.

DAVIS, J.I., STEVENSON, D.W., PETERSEN, G., SEBERG, O., CAMPBELL, L.M., FREUDENSTEIN, J.V., GOLDMAN, D.H., HARDY, C.R., MICHELANGELI, F. A., SIMMONS, M.P., SPECHT, C.D., VERGARA-SILVA, F. \& GANDOLFO, M. 2004. A phylogeny of the monocots, as inferred from rbcL and atpA sequence variation, and a comparison of methods for calculating jackknife and bootstrap values. Systematic Botany 29:467-510.

ESAU, K. 1985. Anatomía vegetal. Ediciones Omega S. A., Barcelona.

FAHN, A. \& CUTLER, D.F. 1992. Xerophytes. Encyclopedia of plant anatomy. Borntraeger, Berlin. 
FINLEY, D.S. 1999. Patterns of calcium oxalate crystals in young tropical leaves: a possible role as an antiherbivory defense. Revista de Biología Tropical 47: 27-31.

FLORES, E.M. 1975. Algunos aspectos de anatomía foliar comparada de dos especies de Bromeliacae (Aechmea mexicana Baker y Hechtia glomerata Zucc.). Revista de Biología Tropical 23:29-52.

GERLACH, D. 1984. Botanische Mikrotechnik. Georg. Thieme Verlag, Stuttgart.

HORRES, R., ZIZKA, G., KAHL, G. \& WEISING, K. 2000. Molecular phylogenetics of Bromeliaceae: evidence from trnl (uaa) intron sequences of the chloroplast genome. Plant Biology 2:306-315.

JOHANSEN, D.A. 1940. Plant microtechnique. McGrawHill Book Company, New York.

KAISER, E. 1880. Verfahren zur Herstellung einer tadellosen glycerin-gelatine. Botanisch Zentralb 180:25-26.

KRAUS, J.E. \& ARDUIN, M. 1997. Manual básico de métodos em morfologia vegetal. EDUR, Seropédica.

KRAUSS, B.H. 1948. Anatomy of the vegetative organs of the pineapple, Ananas comosus (L.) Merr. I Introduction, organography, the stem, and the lateral branch or axillary buds. Botanical Gazette 110:159217.

KRAUSS, B.H. 1949a. Anatomy of the vegetative organs of the pineapple, Ananas comosus (L.) Merr. II - The leaf. Botanical Gazette 110:333-404.

KRAUSS, B.H. 1949b. Anatomy of the vegetative organs of the pineapple, Ananas comosus (L.) Merr. III - The root and the cork. Botanical Gazette 110:550-587.

LINDER, H.P. \& RUDALL, P.J. 2005. Evolutionary history of Poales. Annual Review of Ecology, Evolution and Systematics 36:107-124.

MAUSETH, J.D. 1988. Plant anatomy. The Benjamin/ Cummings Publishing Company, California.

PROENÇA, S.L. \& SAJO, M.G. 2004. Estrutura foliar de espécies de Aechmea Ruiz \& Pav. (Bromeliaceae) do Estado de São Paulo. Acta Botânica Brasílica 18:313331.

PROENÇA, S.L. \& SAJO, M.G. 2007. Anatomia foliar de bromélias ocorrentes em áreas de cerrado do Estado de São Paulo. Acta Botanica Brasilica 21:657-673.

PRYCHID, C.J. \& RUDALL, P.J. 1999. Calcium oxalate crystals in monocotyledons: a review of their structure and systematics. Annals of Botany 84:725-739.

PRYCHID, C.J., RUDALL, P.J. \& GREGORY, M. 2004. Systematics and biology of silica bodies in monocotyledons. Botanical Review 69:377-440.

SAJO, M.G., FURNESS, C.A., PRYCHID, C.J. \& RUDALL, P.J. 2005. Microsporogenesis and anther development in Bromeliaceae. Grana 44:65-74.
SAJO, M.G., MACHADO, S.R. \& CARMELLOGUERREIRO, S.M. 1998. Aspectos estruturais de folhas de bromélias e suas implicações no agrupamento de espécies. Pp.102-111. In: M.V. Pereira (ed.). Bromélias da Mata Atlântica: Canistropsis. Rio de Janeiro, Salamandra Consultoria Editorial Ltda.

SAJO, M.G., PRYCHID, C.J. \& RUDALL, P.J. 2004. Structure and development of the ovule in Bromeliaceae. Kew Bulletin 59:261-267.

SASS, J.E. 1951. Botanical microtechnique. Iowa State College Press, Ames.

SCATENA, V.L. \& SEGECIN, S. 2005. Anatomia foliar de Tillandsia L. (Bromeliaceae) dos Campos Gerais, Paraná, Brasil. Revista Brasileira de Botânica 28:635-649.

SEGECIN, S. \& SCATENA, V. L. 2004a. Anatomia de escapos de Tillandsia L. (Bromeliaceae) dos Campos Gerais, Brasil. Revista Brasileira de Botânica 27:515-525.

SEGECIN, S. \& SCATENA, V.L. 2004b. Morfoanatomia de rizomas e raízes de Tillandsia L. (Bromeliaceae) dos Campos Gerais, PR, Brasil. Acta Botanica Brasilica 18:253-260.

SMITH, L.B. \& DOWNS, R.J. 1974. Pitcairnioideae (Bromeliaceae). Flora Neotropica Monograph 14:1-662.

SMITH, L.B. \& DOWNS, R.J. 1977. Tillandsioideae (Bromeliaceae). Flora Neotropica Monograph 14:6631492.

SMITH, L.B. \& DOWNS, R.J. 1979. Bromelioideae (Bromeliaceae). Flora Neotropica Monograph 14:14932142.

SMITH, L.B. \& TILL, W. 1998. Bromeliaceae. In The families and genera of vascular plants (K. Kubitzki, ed.). Springer, Berlin, v.4, p.74-99.

SOLEREDER, H. \& MEYER, F.J. 1929. Bromeliaceae. In Systematische Anatomie der Monokotyledonen. Gebrüder Borntraeger, Berlin, heft 4, p.80-129.

SOUSA, G.M., ESTELITA, M.E.M. \& WANDERLEY, M.G.L. 2005. Anatomia foliar de espécies brasileiras de Aechmea subg. Chevaliera (Gaudich. ex Beer) Baker, Bromelioideae - Bromeliaceae. Revista Brasileira de Botânica 28:603-613.

SOUZA, R.C.O.S. \& NEVES, L.J. 1996. Leaf anatomy of four Tillandsia species. Bromélia 3:28-39.

SUNELL, L.A. \& HEALEY, P.L. 1979. Distribution of calcium oxalate crystal idioblasts in corms of taro (Colocasia esculenta). American Journal of Botany 66:1029-1032.

TOMLINSON, P.B. 1969. Commelinales - Zingiberales. In Anatomy of the monocotyledons (C. R. Metcalfe, ed.). Oxford University Press, London, v.3, p.193-294.

YOSHIDA, S., OHNISHI, Y. \& KITAGISHI, K. 1962. Histochemistry of silicon in rice plant. III. The presence of cuticle-silica double layer in the epidermal tissue. Soil Science and Plant Nutrition 8:1-5. 